\title{
Tonsillektomi Spesmenlerinin Histopatolojik Retrospektif Analizi
}

\author{
Sedat Aydın*, Eren Boldaz
}

DOI: 10.17944/mkutfd.521354

Sedat Aydın: Prof. Dr. İstanbul Üniversitesi Tıp Fakiltesi, Ağız Yüz ve Çene Cerrahisi Anabilim Dalı, istanbul

Email: sedataydin63@yahoo.com ORCID iD: https://orcid.org/0000-0003-4939-5026

Eren Boldaz: Uzm. Dr. Dr. Lütfi Kırdar Kartal Eğitim ve Araștırma Hastanesi KBB Kliniği, İstanbul Email: eren_boldaz@hotmail.com

ORCID iD: https://orcid.org/0000-0001-9116-4542

Bildirimler/Acknowledgement

* Sorumlu Yazar/Corresponding Author

Çıkar Çatıșması/Conflict of Interest Yazarlar bu makale ile ilgili herhangi bir çıkar çatıșması bildirmemișlerdir.

The authors declare that they have no conflict of interests regarding content of this article.

Maddi Destek/Financial Support

Yazarlar bu makale ile ilgili herhangi bir finansal destek bildirmemișlerdir.

The Authors report no financial support regarding content of this article.

\section{Etik Beyan/Ethical Declaration}

Yazarlar, çalıșma için Kartal Dr. Lütfi Kırdar Eğitim ve Araștırma Hastanesi Klinik Araștırmalar Etik Kurulundan $28 / 08 / 2018$ tarih ve $2018 / 514 / 136 / 8$ sayı ile izin alındığını, çalıșmanın yürütülmesi esnasında Helsinki Beyannamesi 2013, ICJM tavsiyeleri ile COPÉun Editör ve Yazarlar için Uluslararası Standartlarının yanısıra ilgili diğer biyoetik kılavuzların dikkate alındığını beyan etmișlerdir.

Geliș/Received: 02.02.2019

Kabul/Accepted: 07.08.2020

e-ISSN: 2149-3103

Web: http://dergipark.org.tr/mkutfd öz

Tonsillektomi Spesmenlerinin Histopatolojik Retrospektif Analizi

Amaç: Tonsillektomi, özellikle pediyatrik yaș grubunda sıkça yapılan bir ameliyattır. Tonsillektomi spesmenlerinin rutin histopatolojik incelemesinin gerekliliği ise hala tartışmalı bir konudur. Çalıșmamızda kliniğimizde son 5,5 yılda tonsillektomi operasyonu olmuș 12 yaș ve üstü hastaların tonsil materyallerinin histopatolojik dağılımını ve rutin patolojik incelemenin gerekliliği sorgulanmaktadır.

Gereç ve Yöntem: Hastanemiz kulak burun boğaz kliniğinde 2013 ocak ayı ve 2018 temmuz ayı tarihleri arasında çeșitli endikasyonlar ile tonsillektomi operasyonu olmuș 856 hastanın (452 erkek, 404 kadın; ortalama yaș: 34.6, yaș aralı̆ı: 12-92 yaș) anamnezi, şikayetleri, fizik muayene sonuçları ve patolojik sonuçları incelenmiștir.

Bulgular: 856 hastanın patoloji sonuçları değerlendirildiğinde; 50 hastada (\%6) malignite saptanmış olup bu hastaların 36'sında (\%4) lenfoma, 11'inde (\%1) skuamoz hücreli karsinom (SCC), 2'sinde (\%0.2) adenokarsinom metastazı (akciğer ve pankreas adenokarsinomu metastazı), $1^{\prime}$ inde (\%0.1) malign melanom, $1^{\prime}$ inde $(\% 0.1)$ nöroendokrin tümör metastazı olduğu görülmüștür. çalıșmaya dahil edilen hastaların hiçbirinde rastlantısal malignite saptanmamıștır.

Sonuç: Literatürdeki çoğu çalıșmada en sık görülen tonsil malignitesi skuamoz hücreli karsinom ikinci en sık görülen tonsil malignitesi ise lenfoma olarak belirtilmiștir. Çalıșmamızda bu bilginin aksine \%72'lik bir oranla en sık görülen tonsil malignitesi lenfoma, ikinci en sık görülen tonsil malignitesi ise skuamoz hücreli karsinom (SCC) olarak bulunmuștur. Lenfoma saptanan 36 hastanın 19'unda (\%52) ise Diffüz Büyük B Hücreli Lenfoma (DBBHL) alt tipi görülmüș olup bu oran literatür verileri ile uyumlu bulunmuștur. Malignite saptanmıș olan hastaların hepsinde malignite risk faktörü (asimetrik büyümüș, ülsere olmuș veya obsturiktif boyutlara ulașmıș tonsil dokusu, boyunda șişlik, yutma güçlüğü vs) olduğu görülmüș olup ve 856 hastanın hiçbirinde rastlantısal malignite saptanmamış̦ır. Sonuç olarak tonsillektomi spesmenlerinin rutin histopatolojik incelenmesi gerekli olmayabilir ancak risk faktörü tașıyan hastalarda mutlaka histopatolojik inceleme yapilmalıdir.

Anahtar Kelimeler: Histopatoloj; Lenfoma; Malignite; Tonsillektomi

\section{Abstract \\ Histopathologic Retrospective Analysis of Tonsillectomy Specimens}

Aim: Tonsillectomy is a frequent surgical operation in every otolaryngology clinic, especially in the pediatric age group. Pathologic examination of tonsillectomy specimens routinely remains a controversial issue. In this study, we investigated the histopathologic distribution of tonsillectomy materials and the necessity of routine pathologic examination in adult patients who underwent tonsillectomy operation in our clinic for the last 5,5 years

Material and Methods: The tonsillectomy materials of 856 patients (452 males, 404 females, mean age: 34.6 years, range of age: 12-92 years) who underwent tonsillectomy operations between January 2013 and July 2018 in our otolaryngology clinic were examined histopathologically.

Results: Malignancy was observed in 50(6\%) of 856 adult patients and malignancy distribution in these patients is like this; $36(\% 4)$ patients with lymphoma, $11(\% 1)$ patients with squamous cell carcinoma $(\mathrm{SCC}), 2(\% 0.2)$ patients with adenocarcinoma metastasis (lung and pancreatic adenocarcinoma), $1(\% 0.1)$ patient with neuroendocrine tumor metastasis

Conclusion: The most common cause of tonsillar malignancies in literature, is squamous cell carcinoma (SCC) and the second most common cause is lymphoma. In our study we found some information contrary to literature as the most common tonsillar malignancy was lymphoma with 72\% and squamous cell carcinoma (SCC) is the second most common malignancy with frequent rate of \% 22. Diffuse Large B Cell Lymphoma (DBBHL) was the most common malignancy with 19 patients (52\%) in patients with lymphoma and this information is consistent with the literature. All patients with malignancy were clinically diagnosed with a malignancy risk factor such as asymmetric enlarged, ulcerated or obstructive tonsillar tissue, swelling in the neck or swallowing difficulty etc. And none of the 856 patients had malignancy. As a result, routine histopathologic examination may not be necessary in patients with tonsillectomy, but histopathologic examination should be performed in patients with have preoperative risk factors. Keywords: Histopathology; Lymphoma; Malignancy; Tonsillectomy 


\section{GİRIŞ}

Tonsillektomi, başta kronik tonsillit olmak üzere çeşitli endikasyonlar ile özellikle pediyatrik yaş grubunda sıkça yapılan bir operasyondur. Tonsillektominin ağız kokusu, tekrarlayan boğaz ağrısı, yüksek ateş, servikal lenfadenit gibi şikayetlerin azalmasında etkili olduğu ve sık kriptik tonsillit olan hastalarda büyük ölçüde iyileșme sağladığı gösterilmiştir (1). Tonsillektomi endikasyonları sıklıkla kronik tonsillit, peritonsiller apse geçirme, kronik obstrüktif tonsil hipertrofisi, uyku apne sendromu iken nadiren de olsa bir neoplazmı dişlamak veya tekrarlayan tonsiller hemorajiyi durdurmak için tonsillektomi yapılmaktadır $(2,3)$.

Çalışmamızın amacı son 5,5 yılda kliniğimizde yapılmış tonsillektomiler sonucu elde edilen spesmenlerin histopatolojik analizini incelemek ve sonuçların literatür verileri ile uyumluluğunu araştırmaktır. Ayrıca rutin histopatolojik incelenmesinin gerekliliği ve rastlantısal malignite oranları da tartışılacaktır.

\section{GEREÇ VE YÖNTEM}

Çalışmamızda 2013 ocak ayı ile 2018 temmuz ayı arasinda genel anestezi altında tonsillektomi operasyonu olan 12 yaş ve üstü 856 hastanın (452 erkek, 404 kadın; ortalama yaş: 34.6, yaş aralığı: 12-92 yaş) anamnezleri, şikayetleri, fizik muayene sonuçları ve tonsillektomi spesmenlerinin histopatolojik sonuçları incelenmiștir. Brodsky ve ark tarafından önerilen skalaya göre tonsiller arasında +1 ve fazla büyüklük farkı olanlar asimetrik tonsil hipertrofisi kabul edilmiştir. Tüm hastalara genel anestezi altında klasik tonsillektomi uygulanmış olup spesmenlerin hepsi \%10'luk formaldehit solüsyonu içinde patolojiye gönderilmiştir.

Kliniğimizde 12 yaş ve üstü hastaların tonsillektomi spesmenleri rutin olarak patolojiye gönderilmekte olup malignite şüphesi olan (asimetrik büyümüş, ülsere olmuş veya obstrüktif boyutlara ulaşmış tonsil dokusu, boyunda şişlik, yutma güçlüğü vs.) hastalar hariç 12 yaş altı hastalara rutin olarak patolojik inceleme yapılmamaktadır. Literatürde bu yaklaşımı destekler nitelikte birçok çalışma mevcuttur (1,4-9).

\section{Etik Beyan}

Bu çalışma için Kartal Dr. Lütfi Kırdar Eğitim ve Araştırma Hastanesi Klinik Araştırmalar Etik Kurulundan 28/08/2018 tarih ve 2018/514/136/8 sayı ile izin alınmış, çalışmanın yürütülmesi esnasında Helsinki Beyannamesi 2013, ICJM tavsiyeleri ile COPE'un Editör ve Yazarlar için Uluslararası Standartlarının yanısıra ilgili diğer biyoetik kılavuzlardaki öneriler dikkate alınmıştır.

\section{BULGULAR}

Tonsillektomi olan 856 hasta (452 erkek, 404 kadın; ortalama yaş: 34.6 , yaș aralığı: $12-92$ yaş) çalıșmaya dahil edilmiş olup hastaların anamnezleri, şikayetleri, fizik muayene bulguları ve patoloji sonuçları retrospektif olarak analiz edilmiştir. Histopatolojik inceleme sonucunda 856 hastanın 342'sinde (\%39.93) kronik iltihap, 171'inde (\%19.97) lenfoid hiperplazi, 308'inde (\%35.9) ise kronik iltihap ile lenfoid hiperplazi birlikteliği olduğu, ayrıca 113 hastada (\%13) aktinomiçes granülleri, 25 hastada $(\% 2,9)$ skuamoz papillom olduğu görülmüştür. Hastaların 50'sinde (\%6) malignite izlenmiş olup malignite saptanan hastaların 36'sında (\%4) lenfoma, 11'inde (\%1) skuamoz hücreli karsinom (SHK), 2'sinde (\%0.2) adenokarsinom metastazı (akciğer ve pankreas adenokarsinomu), 1'inde (\%0.1) malign melanom, 1'inde (\%0.1) nöroendokrin tümör metastazı saptanmıştır (Tablo 1, Şekil 1).

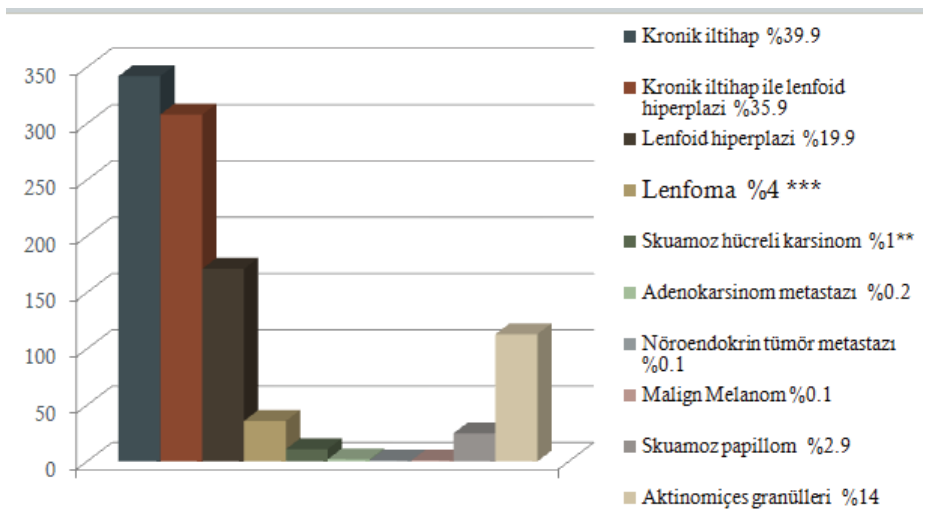

Şekil 1. Tonsillektomi spesmenlerinin histopatolojik dağılımı

Tablo 1. Tonsillektomi spesmenlerinin histopatolojik dağlımı

$\begin{array}{lll}\text { Lezyon } & \mathrm{n} & \% \\ \text { Kronik iltihap } & 342 & 39.93 \\ \text { Kronik iltihap ile lenfoid hiperplazi } & 308 & 35.95 \\ \text { Lenfoid hiperplazi } & 171 & 19.97 \\ \text { Lenfoma } & 36 & 4 \\ \text { Skuamoz hücreli karsinoma } & 11 & 1 \\ \text { Adenokarsinom metastazı } & 2 & 0.2 \\ \text { Nöroendokrin tümör metastazı } & 1 & 0.1 \\ \text { Malign melanom } & 1 & 0.1 \\ \text { Skuamoz papillom } & 25 & 2.9 \\ \text { Aktinomiçes granülleri } & 113 & 13\end{array}$

Tonsil lenfoması saptanan hastalarda sıklık olarak bakıldığında literatür ile uyumlu olarak diffüz büyük b hücreli lenfoma (DBBHL) 19 hasta (\%52) ile birinci surada yer alırken, mantle hücreli lenfoma 5 hasta (\%13) ile ikinci s1rada yer almaktadır. Bu ikisini sırasıyla 3 (\%8) ile marjinal 
zone lenfoma, 2 (\%5) ile foliküler lenfoma, 6 (\%16) ile diğer türler (burkitt lenfoma, küçük lenfositik lenfoma, t hücreli lenfoblastik lenfoma, vs.) izlemektedir (Şekil 2).

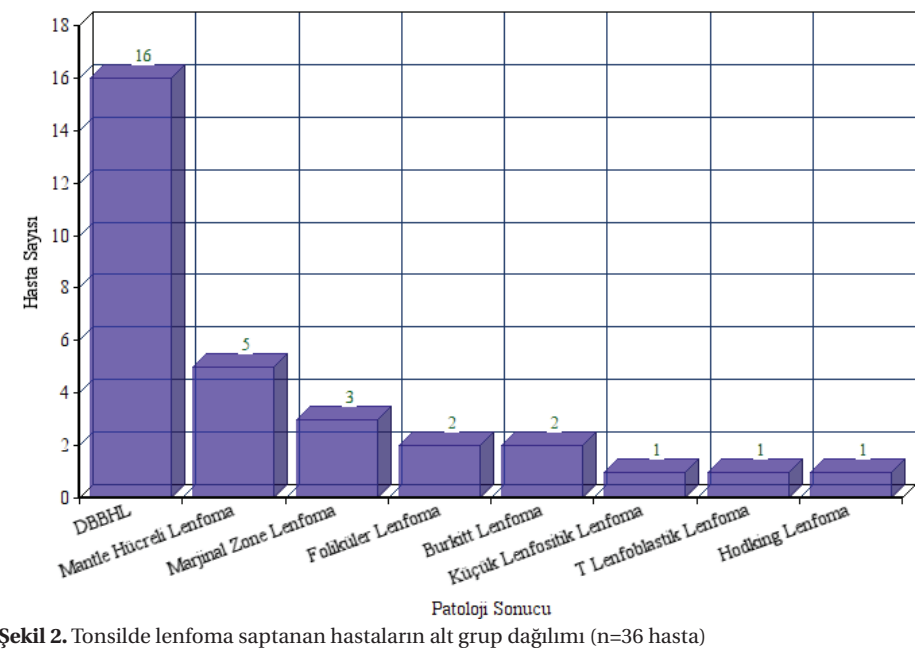

Malignite saptanan hastaların hepsine malignite ön tanısı ile tonsillektomi yapılmış olup bu hastalarda maligniteyi düşündürecek risk faktörleri (asimetrik büyümüş, ülsere olmuş veya obstrüktif boyutlara ulaşmış tonsil dokusu, boyunda şişlik, yutma güçlüğü, kilo kaybı, Hodgkin lenfomaya özgü B semptomları varlığı, malignite, Radyoterapi, Kemoterapi veya immünoterapi öyküsü vs.) mevcut idi. Çalışmamızda 12 yaş üstü 856 adet hastanın tonsillektomi spesmenlerinin incelenmesi sonucunda hiç rastlantısal malignite saptanmamıştır.

Malignite saptanan 50 hastanın şikâyet, hikaye ve fizik muayeneleri analiz edildiğinde tarafımıza başvurunun en çok boyunda şişlik (n:20, \%40) şikayeti ile olduğu bunun yanında hastaların boğaz ağrısı, yutma güçlüğü, boğazda takılma hissi, uyurken nefes almada zorlama şikayetlerinin de olduğu görülmüştür. Fizik muayenede ise en sık rastlanılan bulgunun 44 hasta (\%88) ile tonsil asimetrisi olduğu ikinci en sık rastlanılan bulgunun ise 20 hasta (\%40) ile boyunda şişlik olduğu görülmüştür.

\section{TARTIŞMA}

Tonsilde en sık görülen malignite SHK iken ikinci en sık görülen malignite lenfomadır. Pediatrik yaş grubunda ise en sık görülen tonsil malignitesi lenfomadır $(10,11)$. Çalışmamızda literatür verilerinin aksine en sık görülen tonsil malignitesi \%72 gibi yüksek bir oranla lenfoma olarak bulunmuştur.

Tonsilde görülen lenfomaların büyük bölümü Non-Ho- dgkin lenfoma olup baş boyunda ekstranodal en sık yerleşimi \%24-55 oran ile tonsillerdir. Hodgkin lenfomalar ise nadiren ekstra nodular yayılım göstererek waldeyer halkasını tutmaktadır. Non-Hodgkin lenfomalar içinde en sık tonsilde yerleşim gösteren alt tip DBBHL olup mantle hücreli lenfoma, marjinal zone lenfoma, foliküler lenfoma, burkitt lenfoma, küçük lenfositik lenfoma, t hücreli lenfoblastik lenfoma da görülebilmektedir $(12,13,14)$. Çalışmamız bu bilgilerle uyumlu sonuçlar elde etmiştir.

Lenfoma tanısı alan hastalar başta olmak üzere tonsilde malignite saptanan hastalarda en çok boyunda şişlik şikâyeti olduğu sonrasında ise sırası ile boğaz ağrısı, yutma güçlüğü, boğazda takılma hissi, uyurken nefes almada zorlama şikayetleri olduğu belirtilmiştir. Fizik muayenede ise asimetrik tonsil hipertrofisi en sık görülen bulgu olup boyunda şişlik ise ikinci en sık fizik muayene bulgusudur $(3,5,8)$. Çalışmamız bu bilgilerle uyumlu sonuçlar elde etmiştir.

Çalışmamızda malignite saptanan tüm hastalarda malignite risk faktörü (tonsil asimetrisi, tonsil mukozasında ülserasyon, tonsilde palpasyonla sertlik, servikal lenfadenopati, beklenmedik kilo kaybı ve yapısal semptomlar, malignite, RT veya immün yetmezlik öyküsü vs.) mevcut olduğu izlenmiş olup rastlantısal malignite saptanmamıştır. Günümüzde ister erişkin ister çocuk yaş grubu olsun tonsillektomi operasyonu sonrasinda tonsillektomi spesmenlerinin rutin histopatolojik incelenmesinin yapılmasının gerekliliği hala tartışılmaktadır. Bizzell ve ark yaptığı çalışmada 10 yıllık bir sürede bakılan 8807 tonsillektomi spesmeninin hiçbirinde rastlantısal malignite saptanmamıştır (5). Chow W. ve ark'nın yaptığı çalışmada ise çoğunluğu çocuk olmak üzere son 7 yılda tonsillektomi yapılan 3.724 hastanın tonsillektomi spesmenleri incelenmiş ve hiçbir rastlantısal malignite saptanmamıştır. Bu rutin histopatolojik incelemenin hastaneye maliyeti yıllık $3308 \mathrm{ABD}$ doları olarak bulunmuştur (3). Faramarzi ve ark güney İran'da rutin olarak tonsillektomi spesmenlerini inceledikleri çalışmada yaş ortalaması 14 olan 5058 hastadan sadece l'inde rastlantısal malignite saptandığı bildirilmiş olup bu hastanın 50 yaşında olduğu ve tekrarlayan tonsillit atakları ile beraber tonsil hipertrofisi olması dişında ek bir fiziksel özelliğinin olmadığı belirtilmiştir. Bu hastanın patolojisi lenfoma gelmiş olup 5058 vakalık seride en sık bulunan malignite, çalışmamız ile uyumlu biçimde lenfoma (\%46) olarak saptanmıştır (15). Koç ve ark'nın yaptığı çalışmada ise ortalama yaşı 8 olan 1021 hastanın tonsillektomi spesmenleri patolojik olarak incelenmiş ve rastlantısal malignite bulunamamıştır (6). Kılıçoğlu ve ark'nın yaptığı çalışmada ise son 14 yllın tonsillektomi spesmenleri retrospektif olarak taranmış ve 2410 hastanın hiçbirinde rastlantısal malignite bulunamamıştır. Kılıçoğlu bu yazısında özellikle çocuk yaş grubunda rutin patolojik incelemenin gereksiz olduğunu belirtmiş ve özellikle asimetrik tonsil hipert- 
rofisi, ülsere tonsil olmak üzere malignite düşündürecek durumlarda dikkatli olunması gerektiği uyarısında bulunmuştur (9).

Rokkjaer ve ark'nın yaptığı meta analizde 37 adet makale incelenmiş ve 72,322 hastanın tonsillektomi spesmenlerinin rutin olarak histopatolojik incelemeye gönderildiği, bunun sonucunda sadece 11 hastada (\%0.015) rastlantısal malignite saptandığı izlenmiştir. Hastalarda rastlantısal malignite varlığının olduğunu söylemek için malignite düşündürecek herhangi bir bulgunun (tonsil asimetrisi, tonsil mukozasında lezyon, tonsilde palpasyonla sertlik, servikal lenfadenopati, beklenmedik kilo kaybı ve yapısal semptomlar, malignite, RT veya immün yetmezlik öyküsü) olmadığına dikkat etme gerekliliğinden bahsedilmiştir. Rokkjaer ve ark, çocuk yaş grubunda, 21 çalışmanın araştırıldığı, 21,223 çocuğun çalışmaya dahil edildiği araştırmada 3 çocukta (\%0.01) rastlantısal malignite bulunduğu; erişkin yaş grubunda ise 12 çalışmanın araştırıldığı 6,434 hastanın çalışmaya dahil edildiği araştırmada ise 8 hastada (\%0.05) rastlantısal malignite saptandığı belirtilmiştir (16). Reiter ve ark 1320 erişkin tonsillektomi spesmeninin 1280'inin rutin incelenmesi sonucunda maligniteye rastlamamıştır. 31 hastada malignite risk faktörleri bulunmuş olup sadece 2 hastaya (\%6.5) malignite tanısı konulmuştur. Bu çalışmada 1939 ile 1997 yılları arasındaki literatür incelemesi de yapılmış olup 29.461 tonsillektomi spesmeninde 4 adet rastlantısal malignite (\%0.01) bulunmuş ve düşük insidans nedeni ile histopatolojik incelemenin sadece şüpheli olgularda yapılabileceği bildirilmiştir (17). Courville ve ark yaptığ çalışmada 1.746 erişkin hastanın tonsillektomi spesmenleri incelenmiş ve rastlantısal malignite saptanmamıştır. Ayrıca Courville ve ark kliniğimize benzer bir uygulama ile son araştırmalar ışığında rutin olarak çocuk tonsillektomi spesmenlerinin histopatolojik incelenmesinin gereksiz olduğunu bildirmiştir ve kendi kliniklerinde çocuk hastalarda rutin inceleme yapmadıklarını belirtmiştir (7). Dewil ve ark'nın yaptığı çalışmada son 7 yılda yapılan tonsillektomi spesmenleri rutin olarak incelenmiş ve inceleme sonucunda rastlantısal malignite saptanmamış, sadece 20 erișkin hastada malignite saptanmış olup bu hastalarda da malignite için risk faktörleri (özellikle tonsil asimetrisi olmak üzere) mevcut olduğu izlenmiştir (8).

\section{SONUÇ}

Tonsillektomi yapılacak olan hastaların özellikle asimetrik tonsil ve boyunda şişlik gibi malignite düşündürecek bulguları varsa mutlaka histopatolojik incelemeye tabi tutulması gerekmektedir. Fakat yaptığımız bu çalışma ve literatürdeki diğer çalışmalar ışığında özellikle çocuk yaş grubunda rastlantısal malignite oranının çok düşük olduğunu görmekteyiz ve bundan dolayı tonsillektomi spesmenlerinin rutin histopatolojik incelenmesinin gerekli olmayabileceğini düşünmekteyiz. Eğer bu yaklaşım uygulanırsa tonsillektomi olan hastaların hastane maliyeti de önemli ölçüde düşecektir.

Histopatolojik analizimizde ise literatürdeki çalışmaların aksine tonsilde en sık görülen malignitenin lenfoma olduğu ikinci en sık görülen malignitenin ise SHK olduğu; tonsil lenfomaları içinde ise literatür ile uygun olarak en sık görülen lenfoma alt tipinin DBBHL olduğu görülmektedir.

\section{Kaynaklar}

1. Chow W Rotenberg BW Discontinuing routine histopathological analysis after adult tonsillectomy for benign indication. Laryngoscope. 2015 Jul;125 (7) :1595-9

2. Koskenkorva T, Koivunen P Short-term outcomes of tonsillectomy in adult patients with recurrent pharyngitis: a randomized controlled trial CMAJ. 2013 May 14;185 (8) :E331-6.

3. Mustafa K , Selçuk Y. Current approach to adenotonsillectomy in children Balıkesir Sağlık Bilimleri Dergisi 2015:2146-9601

4. Booth CL, Wang J. hematologic malignancy in routine tonsillectomy specimens: a single institutional experience and review of the literature. Am J Clin Pathol. 2013 Dec;140 (6) :807-12

5. Jamie Glancy Bizzell ,Gresham T. Richter Routine pathologic examination of tonsillectomy specimens: A 10-year experience at a tertiary care children's hospital International Journal of Pediatric Otorhinolaryngology2017-11-01,

6. Koç S, Uysal IO, Histopathologic examination of routine tonsil and adenoid specimens: is it a necessary approach? Kulak Burun Bogaz Ihtis Derg. 2012 Mar-Apr;22 (2) :87-90.

7. Courville EL, Lew M, Sadow PM. Routine evaluation of adult tonsillectomy specimens: toward establishing a new standard of care. Int J Surg Pathol. 2011 Aug;19 (4) :469-75.

8. Dewil B, Jorissen M, Lemkens P. Routine pathological evaluation after tonsillectomy: is it necessary?B-ENT. 2006;2 (3) :103-8.

9. Kalcioglu MT, Gurses I, Erdem T. Is the pathological examination of routine tonsillectomy and adenoidectomy specimens necessary? A retrospective study of 559 adenoidectomy and 1132 tonsillectomy specimens and a literature review. B-ENT. 2010;6 (2) :91-5.

10.S Syrjanen HPV infections and tonsillar carcinoma Clin Pathol 2004;57:449-455.

11. Anil K. Chaturvedi, Eric A. Engels Incidence Trends for Human Papillomavirus-Related and -Unrelated Oral Squamous Cell Carcinomas in the United States Journal of Clinical Oncology 2008 $26: 4,612-619$

12. Iyengar P, Mazloom A, Shihadeh F, et al. Hodgkin lymphoma involving extra-nodal and nodal head and neck sites: characteristics and outcomes. Cancer2010;116 (16) :3825-9.

13. Chi H-S, Lee K-W, Chiang F-Y, et al. Head and neck extranodal 
lymphomain a single institute: a 17-year retrospective analysis. Kaohsiung J Med Sci2012;28 (8) :435-41.

14. Etemad-Moghadam S, Tirgary F, Keshavarz S, et al. Head and neck non-Hodgkin's lymphoma: a 20-year demographic study of 381 cases. Int J oralmaxillofac Surg 2010;39 (9):869-72.

15. A. Faramarzi, M.J. Ashraf, B. Hashemi Histopathological screening of tonsillectomy and/or adenoidectomy specimens: A report from southern Iran International Journal of Pediatric Otorhinolaryngology,
2009-11-01,7;1576-1579

16. Rokkjaer MS, Klug TE. Malignancy in routine tonsillectomy specimens: a systematic literature review. Eur Arch Otorhinolaryngol. 2014 Nov;271 (11) :2851-61.

17. Reiter ER, Randolph GW, Pilch BZ. Microscopic detection Of malignancy in the adult tonsil.Otolaryngol Head Neck Surg. 1999;120:190-4. 